\title{
The Cold War International History Project
}

The Cold War International History Project was established by the Woodrow Wilson International Center for Scholars in 1991.The project supports the full and prompt release of historical materials by governments on all sides of the Cold War and seeks to disseminate new information and perspectives on Cold War history emerging from previously inaccessible sources on "the other side" - the former Communist world-through publications, fellowships, and scholarly meetings and conferences. The project publishes the Cold War International History Project Bulletin and a working paper series and maintains a Web site at www.cwihp.org.

At the Woodrow Wilson Center, the project is part of the History and Public Policy Program, directed by Christian F. Ostermann. Previous directors include David Wolff (1997-98) and James G. H ershberg (1991-97). The project is overseen by an advisory committee chaired by William Taubman, Amherst College, and includes Michael Beschloss; James H. Billington, Librarian of Congress; Warren I. Cohen, University of Maryland at Baltimore; John Lewis Gaddis, Yale University; James G. Hershberg, George Washington University; Samuel F. Wells Jr., Woodrow Wilson Center; and Sharon Wolchik, George Washington University.

The Cold War International History Project has been supported by the Korea Foundation, Seoul; the Leon Levy Foundation, New York; the Henry Luce Foundation, New York; the John D. and Catherine T. MacArthur Foundation, Chicago; and the Smith Richardson Foundation, Westport, Conn. 
For Annie, Gabriel, and Vera Hershberg and for my parents, Arline and David Hershberg 
